\title{
On Property and Constitutionalism
}

\section{Citation}

Cass R. Sunstein, On Property and Constitutionalism (Program in Law \& Economics Working Paper No. 3, 19911.

\section{Published Version}

http://chicagounbound.uchicago.edu/law_and_economics/341/

\section{Permanent link}

http://nrs.harvard.edu/urn-3:HUL.InstRepos:12809430

\section{Terms of Use}

This article was downloaded from Harvard University's DASH repository, and is made available under the terms and conditions applicable to Other Posted Material, as set forth at http:// nrs.harvard.edu/urn-3:HUL.InstRepos:dash.current.terms-of-use\#LAA

\section{Share Your Story}

The Harvard community has made this article openly available.

Please share how this access benefits you. Submit a story.

Accessibility 


\section{University of Chicago Law School Chicago Unbound}

Coase-Sandor Working Paper Series in Law and

Economics

Coase-Sandor Institute for Law and Economics

1991

\section{On Property and Constitutionalism}

Cass R. Sunstein

Follow this and additional works at: http://chicagounbound.uchicago.edu/law_and_economics Part of the Law Commons

\section{Recommended Citation}

Cass R. Sunstein, "On Property and Constitutionalism" (Program in Law and Economics Working Paper No. 3, 1991).

This Working Paper is brought to you for free and open access by the Coase-Sandor Institute for Law and Economics at Chicago Unbound. It has been accepted for inclusion in Coase-Sandor Working Paper Series in Law and Economics by an authorized administrator of Chicago Unbound. For more information, please contact unbound@law.uchicago.edu. 


\section{ChICAgo}

Law $\&$ Economics Working Paper No. 3

(2D SERIES)

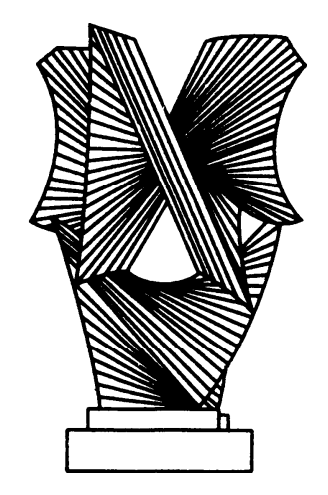

OnPRoperty and CONSTITUTIONALISM

Cass R. Sunstein

THE LAW SCHOOL

THE UNIVERSITY OF CHICAGO 


\section{OnProperty and Constitutionalism}

\section{Cass R. Sunstein ${ }^{*}$}

\section{INTRODUCTION}

$\mathrm{T}^{\mathrm{t}}$ is generally understood that the recent revolutions in Eastern 1 Europe are producing a large-scale "transition." It is important, however, to distinguish among the quite different features of the current changes. The new reform movements actually involve three distinctive transitions. The first is a transition from a command economy to markets. The second is a transition from a system of one-party domination to democracy. The third is a transition from a system in which government is unconstrained by laws laid down in advance to constitutionalism and the rule of law.

Although important work is occurring on all these fronts, participants in current debates generally assume that the three transitions are not closely connected. At the present. and for the foreseeable future, it seem; clear that the transition to markets, and the accompanying efforts to promote economic development, will be foremost in the minds of the reformers. Democratization appears also on the agenda, but it is taking a secondary role. In the meantime, the movement for constitutional reform generally draws little public attention, and indeed has been dwarfed by other matters. In many circles, the drafting of the Constitution is thought to involve symbolic or even irrelevant matters having no real connection to the hard pragmatic work of economic and political reform.

I believe that the separation of the three transitions, and the devaluation of constitution-writing, are extremely unfortunate and potentially dangerous mistakes. In fact the transitions are closely re-

* Karl N. Llewellyn Professor of Jurisprudence, The Law School and Department of Political Science, The University of Chicago; Co-Director, Center on Constitutionalism in Eastern Europe, The University of Chicago. I am grateful to Richard A. Epstein and Stephen Holmes for helpful comments on a previous draft. Different versions of some of this essay will appear in Constitutional Political Economy and in the Cardozo Law Review.

Copyright (C) 1991 by Cass R. Sunstein. 
lated. The right kind of constitution could play a crucial role in fueling economic development and democratic reform; indeed, it may be indispensable to them. The wrong kind of constitution-or no constitution at all-could be devastating to both of these.

To offer only one example: Firm constitutional Protection of property rights, combined with an independent judiciary is an excellent way of encouraging international investment in one's nation. Such devices should spur domestic investment and initiative as well. Without such constitutional protection, there will be a serious obstacle to the necessary economic activity from international and domestic enterprises. Anyone who engages in these activities will do so with knowledge that the state may take their property or abrogate their contracts. To say the very least, this will be an obstacle to economic development.

In Eastern Europe, there is a far more pressing need for constitutional protection of economic and democratic rights than there was in the United States or the West. In the United States, for example, the process of constitution-making was much simplified by virtue of the fact that well before that process began, private property, the common law, and civil society were firmly in place. The constitution-makers could build on, and attempt to protect, existing achievements. The market and the institutions of civil society-private intermediate associations operating between the individual and the state, including religious organizations, charitable trusts, local community groups, business enterprises-antedated the Constitution.

The task of constitution-making in Eastern Europe is both more critical and more daunting, precisely because of the absence of well-established institutions protecting market ordering and civil society. The emerging constitutions must not only create the basic governmental structures and protect the conventional catalog of liberal rights, but also concern themselves with the creation of safeguards for the transition to (some version of) market ordering. If they fail to do so, a large amount of the important work will occur on the legislative front, where there may be special barriers to success. A particular problem is that democratic politics may make it difficult to create real markets, which produce such transitional problems as inflation and unemployment. Even more fundamentally, the process of constitution-making could become irrelevant to 
many of the fundamental issues now facing Eastern Europe. There is a serious current danger that the moment of constitutional opportunity will be irretrievably lost; and if it is, both prosperity and democratization will be at risk

This essay comes in three parts. The first briefly discusses the relationships among property, democracy, and economic growth. My principal goal is to show that property should be seen as a political right, one that reduces dependence on the state and creates the kind of security that is indispensable to genuine citizenship in a democracy. Property rights are not in conflict with democracy; in a variety of ways they help provide the preconditions for self-governance. The creation of private property also serves a number of functions indispensable to economic development.

The second part speculates about the contents of a constitution that is self-consciously designed, as Western constitutions have not entirely been, to create a market economy and to promote the institutions of civil society. My particular goal here is to argue that constitutionalism can play a crucial role in protecting both economic development and democratic self-government. A well-drafted constitution can guard against a system in which ownership rights are effectively subject to continuous political revision; such a system reintroduces all of the problems, both economic and democratic, introduced by common ownership of property. Through cataloguing possible provisions, I hope to begin a process of helping to develop a kind of "economic bill of rights" for constitution-making in Eastern Europe. Such a development might ultimately count as one of a range of contributions of the recent events to the theory and practice of constitutionalism, and to the long-overdue integration of economics and constitutionalism.

The third part deals with two problems that cannot be solved through constitution-making. The first problem is that of interpretation. The meaning of any text is a function of interpretive principles, and these cannot be spelled out in the text itself. The second problem is the task of initially allocating entitlements. That task must be undertaken through ordinary legislation, and it will have a range of surprising effects. 


\section{Property, Prosperity, Democracy}

We should begin by distinguishing between two sorts of constitutions. Westerners often think that Soviet-style constitutions are not constitutions at all. In fact, however, they embody a distinct conception of constitutionalism. Crucially, such constitutions do not distinguish between public and private spheres. They apply their prohibitions and permissions to everyone.

Moreover, such constitutions contain duties as well as rights. They do not merely grant privileges to citizens, but also impose obligations on them. Finally, and most important of all, the central provisions of Soviet-style constitutions set out very general social aspirations or commitments. Their provisions are designed to state those aspirations, not to create concrete entitlements that citizens can attempt to vindicate, through an independent judiciary, against government officials. These aspirations include a wide range of "positive" rights.

Thus, for example, the Soviet Constitution includes the right to work (Art. 40), the right to rest and leisure (Art. 41), the right to health protection (Art. 42), and the right to maintenance in old age, sickness, and disability (Art. 43). It imposes on citizens the duty to "preserve and protect socialist property" and to "enhance the power and prestige" of the Soviet State (Art. 62). The Polish Constitution includes the right to work (Art. 68), the right to rest and leisure (Art. 69), and the right to health protection (Art. 70). The Romanian Constitution includes the right to leisure (Art. 19), the right to work, including equal pay for equal work and measures for the protection and safety of workers (Art. 18); the Bulgarian Constitution offers the right to a holiday (Art. 42), the right to work (Art. 40), the right to labor safety (Art. 41), the right to social security (Art. 43), and the right to free medical care (Art. 47).

Along each of these dimensions, Western constitutions are quite different. The provisions of such constitutions generally apply only to the government, and not to private actors. They do not impose duties. Most important, they aim to create solid individual rights, ones that can be invoked by individual citizens, as of right, in an independent tribunal authorized to bar governmental action. Western constitutions generally do not include broad aspirations. 
The individual rights protected by Western constitutions are not, of course, limited to private property and economic liberties. They include other political and civil liberties and rights as well, and these are indispensable safeguards. My principal goal here, however, is to understand how constitutionalism might work simultaneously to promote the transition to economic markets and the transition to democracy, and for this reason it will be valuable to focus on the right to private property. In this section, I briefly outline some of the functions served by that right. The basic story should be familiar. I recount it here because it seems especially important to keep it in mind while exploring the recent wave of constitution-making in Eastern Europe.

\section{A. Private Property and Economic Prosperity}

It is generally agreed that a system of private property helps to bring about economic prosperity. There are at least four central reasons.'

First, the institution of private property ${ }^{2}$ creates and takes advantage of the powerful human inclination to bring goods and services to oneself and to people one cares about. ${ }^{3}$ This claim does not depend on a proposition about human selfishness. The desire to acquire goods might be deeply altruistic, in the sense that people may want to give their goods to others, including the most vulnerable.

In a system of private property, the gains from the use and cultivation of ownership rights accrue to a designated owner. A system without private property stifles incentives and thus induces both (1988).

${ }^{1}$ I draw in this section on J. Waldron, The Right to Private Property

2 As a technical matter, a system of private property should not be identified with a market economy. The distinguishing feature of a market economy is free alienability of ownership rights. The distinctive feature of a system of private property is that individuals are entitled to decide how resources will be used. See J. Waldron, supra note 1 , at 60 . In practice, however, these closely related ideas tend to go hand-in-hand.

3 Aristotle made the basic point: "Men pay most attention to what is their own: they care less for what is common; or, at any rate, they care for it only to the extent to which each is individually concerned." See Aristotle, Politics, 1261 (p.44) (trans. Barker). 
sloth and waste. ${ }^{4}$ These points, too, do not depend. on especially cynical accounts of human nature. It is necessary only to glance briefly at history, past and present, and to acknowledge that human beings will frequently attempt to accumulate resources. Social institutions appealing to this inclination will increase social productivity.

Second, a system of private property performs a crucial coordinating function. It ensures that the multiple desires of hundreds, thousands, or millions of consumers will be reflected in market outcomes. In this way it protects against the perverse forms of scarcity produced by a command economy. Public officials cannot possibly know what and how much people will want in advance. Their decisions will thus create both too much and too little production. By contrast, a system of ownership rights signals people to devote their productive activity to places in which that activity is most valued. A command-and-control economy is far inferior in this regard. Every citizen of Eastern Europe has seen multiple illustrations.

Third, the institution of private property solves, all at once, a serious collective action problem faced by people in any system without that institution. ${ }^{5}$ When property is unowned, no one has a sufficient incentive to use it to its full advantage or to protect it against exploitation. The creation of private property overcomes this problem. It ensures that externalities from use will be internalized by people who are producing either social harms or social benefits. ${ }^{6}$

The point can be made more vivid by a glance at the problem of environmental deterioration. In recent years, it has been increasingly recognized that that problem-especially severe in Eastern Europe

${ }_{4}$ This is a claim about the likely facts, not a necessary truth. Powerful social norms may operate as a surrogate for private property, helping to overcome some of the problems discussed in text. Cf. Ullmann-Margalit, The Emergence of Norms (1978).

5 The point is elaborated in Demsetz, Toward a Theory of Property Rights, Am. Econ. Rev.: Proceedings and Papers 57 (1967).

6 The text uses a pre-Coasian understanding of both harms and benefits, see Coase, The Problem of Social Cost, 3 J. Law \& Econ. 1 (1960); that is, it assumes that we can know without much reflection what sorts of things are "costs" of what sorts of activities. As Coase would have it, costs should be seen as relational entities produced by acts and omissions by many people and not clearly attributable to any one of them. An understanding that something is a cost of something else looks like a descriptive proposition, but it must actually be justified on moral grounds. 
but of critical importance in the West as well-is in significant part ${ }^{7}$ a product of the collective action problem produced by the fact that the air and water are public goods, that is, collectively rather than privately owned. ${ }^{8}$ The consequence is that the environmental costs of polluting activity are widely diffused among the public and not "internalized," or taken into account, by polluters. Because they do not bear the direct cost, polluters lack an incentive to limit their polluting activity. This system creates a built-in tendency toward excessive pollution levels.

A system without private property can be understood as a massive version of this unfortunate state of affairs. If property is unowned, everyone has an incentive to exploit it, and no one has an incentive to use it to its full advantage. Activity levels will have no relationship to their actual social costs and benefits. ${ }^{9}$ Ownership rights overcome the difficulty. They operate like a well-functioning system of environmental law; they ensure that people have incentives to take account of both the benefits and the harms of what they do. This is an exceedingly important task for a constitutional democracy.

Finally, a system of private property creates the kind of stability and protection of expectations that are preconditions for investment and initiative, from both international and domestic sources. A company deciding whether to invest in a country will have a greater incentive to do so if it knows that its investment will be protected, and that government confiscation is prohibited by the government's basic law. A citizen who is seeking to begin a business will be far more likely to do so if he can operate against a secure and stable background, protected against the vicissitudes of government policy. In this way, too, economic development can be facilitated by property rights.

7 This is not, of course, the only possible understanding of the environmental problem. There are other, noneconomic reasons to think that the level of pollution is too high. See S. Kelman, What Price Incentives? (1982).

${ }^{8}$ Hardin, The Tragedy of the Commons, 162 Science 1243 (1968).

9 I do not mean to endorse here the economic conception of costs and benefits, which is based on private willingness to pay and which will be unacceptable for many purposes. On any valuation, however, a system of collective ownership threatens to create the dangers mentioned in the text. 


\section{B. Property and Democracy}

The connection between property and prosperity may be reasonably well understood; but the right to private property has not always been considered a precondition for democracy. On the contrary, private property has frequently been thought an obstacle to democracy, and for this reason highly objectionable, or perhaps at best an institution necessary for economic growth and therefore to be reluctantly accepted, despite its corrosive effects on the democratic process. ${ }^{10}$

There is indeed some tension between a system of property rights and a system of democracy. If property rights are secure, there is a firm limit on what the democratic process is entitled to do. In this sense the tension is a real and enduring one. Notably, markets impose conspicuous short-term costs ${ }^{11}$ - unemployment and inflation-and in the emerging Eastern European democracies, there will probably be. a continuous temptation to slow down the transition to markets or perhaps to reject the transition altogether. For this reason the simultaneous transition to democracy and to economic markets-without the protection of constitutionalism-will be exceptionally difficult.

In important respects, however, it is quite plausible to think that the right to a stable system of property rights-one with which the state will interfere only occasionally or in a limited way, with a provision for compensation - i s actually necessary. to democracy and not opposed to it at all.

The most fundamental point about the relationship between property and democracy is that a right to own private property has an important and salutary effect on the citizens' relationship with the state and-equally important- o $n$ their understanding of that relationship. Because of this effect, it can be seen as a necessary precondition for the status of citizenship. Personal security and personal independence from the government are guaranteed in a system in which rights of ownership are protected through public institutions.

This theme has played a large role in republican thought. On the republican view, the status of citizen implies a measure of inde-

${ }^{10} \mathrm{I}$ do not deal here with the relationship between individual development and property rights, though I believe that property rights do in fact promote that goal. For a good discussion, see J. Waldron, supra note 1, ch. 10 .

${ }^{11}$ And long-term ones as well. 
pendence from government power. This view was often associated with exclusionary practices $\mathrm{s}$, for example, in the notion that people without property should not be allowed to vote. One may deplore the exclusion without rejecting the proposition that a democratic state should attempt to give citizens a sense of independence from the state itself. In fact the republican tradition, read in light of modern understandings, argues not for an abolition of private property but instead for a system attempting to ensure that everyone has some.

In this sense, the ownership of private property is closely associated with the rule of law. ${ }^{12}$ Both of these create a realm of private autonomy in which the citizenry can operate without fear of public intrusion. That realm is indispensable to the public sphere itself. Only people with a degree of security from the state are able to participate without fear, and with independence, in democratic deliberations. In this sense, a sharp, legally-produced distinction between the private and the public can usefully serve the public sphere. Contrary to a conventional understanding, it need not harm it at all. ${ }^{13}$

Even more fundamentally: The division between private and public spheres is hard to defend or even to understand if it is treated as a metaphysical one, or as a claim that public power is not behind the private sphere. But if we understand the division as a political one, to be justified in public terms, it becomes both intelligible and indispensable. The (legal) creation of a private sphere, undertaken by the state, is a key part of the process of creating civil society and market ordering. If these can be justified, the private sphere itself becomes unproblematic, at least in the abstract. Of course its particular

12 F. Hayek, The Road to Serfdom (1948). Initially Hayek's discussion of this point seems exceptionally confusing. He identifies markets and property on the one hand with the rule of law on the other; but the rule of law seems to imply, not necessarily markets and property, but instead firm constraints on official discretion and institutions to enforce those constraints. Such constraints can be created with or without property, that is, a command economy can set down clear rules in advance. (Consider some of the American law of environmental protection, which relies on command-and-control methods, but which usually does not delegate open-ended authority to bureaucrats.) But the identification seems more plausible in light of the considerations discussed in the text.

${ }_{13}$ Cf. Holmes, Gag Rules and Democracy, in Constitutionalism and Democracy (J. Elster \& A. Hylland eds. 1988). 
content can always be criticized, and is frequently subject to democratic redefinition.

The creation of private property can also be connected with the traditional proscription on punishment by reference to vague laws or punishment without laws at all. ${ }^{14}$ That proscription is designed to provide the citizenry with a wall of personal security, creating zones of freedom in which people can operate without fear. A system of private property performs closely related functions.

A central point here is that in a state in which private property does not exist, citizens are dependent on the good will of government officials, almost on a daily basis. ${ }^{15}$ Whatever they have is a privilege and not a right. They come to the state as supplicants or beggars, rather than as rightholders. Any challenge to the state may be stifled or driven underground by virtue of the fact that serious challenges could result in the withdrawal of the goods that give people basic security. A right to private property, free from government interference, is in this sense a necessary basis for a democracy.

In American law, the unconstitutional conditions doctrine operates as a response to this concern in the context of funding, licensing, and employment. ${ }^{16}$ The government may not use its power to grant (say) welfare benefits as a way to pressure the exercise of free speech rights. In fact, the creation of property rights should be seen as an unconstitutional conditions doctrine writ very large. The idea is that government may not use its power over property to pressure rights in general; the existence of property rights generates a strong barrier against this form of pressure. just as the unconstitutional conditions doctrine provides a degree of insulation in narrower settings.

There is a more particular sense in which private property helps to promote resistance to government. If government owns the presses, or the means of distribution, freedom of speech cannot easily

14 See the classic discussion in L. Fuller, The Morality of Law (1964).

15 The demoralizing effects of such regimes are well known to citizens of Communist nations, and indeed to visitors as well. Continuous dependence on government officials has a range of predictable corrosive effects on both character and spirit-a worthy subject for inquiry by a modern Tocqueville.

16 See generally Sullivan, Unconstitutional Conditions, 102 Harv. L. Rev. 1413 (1989); Epstein, Unconstitutional Conditions, State Power, and the Limits of Content, 102 Harv. L. Rev. 4 (1988). 
exist. Indeed, if government owns the paper itself, or allocates it in its discretion, there will be serious problems for the system of free expression. More generally, private ownership facilitates the kind of security on which diversity and pluralism depend. Political censorship may be altogether unnecessary if it is understood that current holdings are vulnerable to state control.

The final point is that one of the best ways to destroy a democratic system is to ensure that the distribution of wealth and resources is unstable and constantly up for new evaluation by the political process. A high degree of stability is necessary in order to allow people to plan their affairs, to reduce the effects of factional or interest-group power in government, to promote investment, and to prevent the political process from breaking down by attempting to resolve enormous, emotionally laden issues about who is entitled to what. Stability and security-a sense of context-are important individual and collective goods. A system in which property rights are open to continuous readjustment will produce serious harm. ${ }^{17}$

In addition, government control of property-through constant readjustment of ownership rights-simply reintroduces the collective action problem originally solved by property rights. Public choice theory can be seen in part as a generalization of this simple insight.

Like the right to freedom of religious conscience, ${ }^{18}$ moreover, the right to property helps create a flourishing civil society, an intermediate level between the government and the individual. The development of a civil society can in turn be understood as a mechanism both for creating economic prosperity and for promoting democratic self-governance. A constitutional system that respects private property should be regarded, not as an effort to oppose liberal rights to collective self-government, but instead as a way to fortify democratic processes.

I have not dealt with the question of redistribution. In the West, enthusiasm for property rights is often thought to entail a reluctance' to allow redistribution, or (worse) complete indifference to the poor. The proper response is twofold; First, property rights help create wealth, and greater wealth will often benefit the most vulner-

\footnotetext{
${ }^{17}$ For this reason the embrace of "context-smashing" in R. Unger, Politics (1985), seems most puzzling.

${ }^{18} \mathrm{Cf}$. Holmes, supra note 13.
} 
able as well. Time and again it has been shown that economic growth does more than welfare and employment programs to benefit the disadvantaged. Of course growth does not do everything, and it must be supplemented. The second point, then, is that welfare and employment programs are a necessary part of any system of property rights. Such rights are best defended in self-consciously instrumental terms, because of the good things that they do. When they do not accomplish good, or enough good, they must be accompanied by other social strategies.

Properly understood, the defense of property rights is a defense of programs of redistribution as well. These programs are not designed to produce economic equality-a truly disastrous goal-but instead to bring about genuine equality of opportunity and, equally important, freedom, for all people in society, from desperate conditions, or from circumstances that impede human functioning. ${ }^{19}$

\section{Property and Constitution-Making}

I have said that the task of economic development cannot be rigidly separated from the task of constitution making. Without constitutional protection of property rights, there will be continuous pressure to adjust distributions of property on an ad hoc basis. When a group of people have acquired a good deal of money, it will be tempting to tax them heavily. When another group has verged on bankruptcy, there will be a temptation to subsidize them. After the fact, these steps may seem fair or even necessary; but if everyone knows that government might respond in this way, there will be a powerful deterrent to the creation of a market economy. No citizen- a nd no international or domestic investor-can be secure of his immunity from the state.

A pervasive risk is that governmental control over property rights will undo the decision, made in the basic system creating such rights, to solve a collective action problem faced-by public ownership. If property rights are insecure-if they are subject to continuous governmental examination- $\mathrm{t} h \mathrm{e}$ system will approach equivalence to one in which there are no such rights at all. This will introduce all

19 See Nussbaum, Aristotelian Social Democracy, in Liberalism and the Good (R. Douglass, G. Mara, \& H. Richardson, eds., 1990); A. Sen, Commodities and Capabilities (1985). 
of the problems, described in Part I, to which a system of property rights is supposed to respond. Above all, it will create individual vulnerability to government and at the same time produce both too little and too much use of existing resources. It will deter economic development and impair the movement toward democracy as well.

\section{A. In General}

I have claimed that a constitution can accomplish a great deal in easing the transition to economic markets and private property. In order for it to do so, constitutional protections must be judicially enforceable-that is, a court must be available to vindicate any rights that the constitution creates. Ordinary citizens must have a general right to raise constitutional objections before an independent tribunal authorized to provide redress. Without judicial review, constitutions tend to be worth little more than the paper on which they are written. They become simple words, or public relations documents, rather than instruments that confer genuine rights. While the efficacy of courts in social reform is disputable, ${ }^{20}$ there can be little doubt that judicially enforceable constitutions can have a significant effect both on real-world results and on legal and social culture in general. ${ }^{21}$ To be sure, some nations in the West have prospered with little or nothing in the way of judicial enforcement of constitutions. But these nations were able to benefit from the background of civil society, market economies, and well-defined property rights. For them, constitutional protections were far less important.

For Eastern Europe in general, the drafting of the constitution appears to pose two especially distinctive challenges. The first is to begin the process of creating a legal culture with firm judicial protection of individual rights. By individual rights, I mean, first and foremost, traditional "negative" rights against government, prominent among them private property and freedom of contract. It is of course misleading to think of these as genuinely negative rights. They depend for their existence on governmental institutions will-

20 See $\Upsilon$ ? Rosenberg, The Hollow Hope (1991)

${ }^{21}$ Much of the effect is deterrence of harmful governmental action before the fact, rather than governmental losses in actual litigated cases. The fear of losing in court has often proved a substantial deterrent to government. 
ing to recognize, create, and protect them. But this point is a semantic one; the defense of the traditional rights need not depend on the false claim that they are negative.

The second challenge is to facilitate the creation of a market economy and of a civil society-that is, a realm of private action containing institutions (churches, markets, corporations, labor unions, women's organizations, and so forth) that are independent of the state and constrained minimally by it. Through meeting these challenges, a constitution could simultaneously promote democratic goals and help bring about economic prosperity.

To carry out this task, constitution-makers should avoid three strategies that contain serious risks. All of these strategies are characteristic features of communist constitutionalism. Unfortunately, all of them appear to be influencing current debates in the post-communist era. The draft Constitutions tend to replicate the errors of the communist constitutions themselves. ${ }^{22}$

1. Aspirations. The first such strategy is to use a constitution as a place for setting out very general social aspirations, or for imposing positive duties on government (such as the provision of a social welfare state including such guarantees as equitable remuneration, leisure time, social security, and occupational safety and health). There are three reasons why this would be a dangerous strategy, at least under current conditions.

First, to state aspirations and impose positive duties-prominent of course in the Soviet Constitution-runs the risk of turning a constitution into something other than a legal document with realworld consequences. It is important to remember that if it is to create rights realistically enforceable in the world, a constitution should not list all things to which a country aspires. It should limit itself, for the most part, to rights that it is genuinely able to enforce. A constitution that creates positive rights is not likely to be subject to judicial enforcement, because these rights are vaguely defined, simultaneously involve the interests of numerous people, and depend for their existence on active management of government institutionssomething for which judges are ill-suited. The existence of unen-

22 These draft Constitutions are on file with the Center on Constitutionalism in Eastern Europe, University of Chicago Law School, and can be obtained from that Center. 
forceable rights will in turn tend to destroy the negative rightsfreedom of speech, freedom of religion, and so forth-that might otherwise be genuine ones. If some rights are shown to be unenforceable, it is likely that other rights will be unenforceable as well.

The second problem with positive rights is that they will work against the general current efforts to diminish the sense of entitlement to state protection, and to encourage individual initiative and self-reliance. Both markets and democracy tend to develop these highly salutary characteristics. Sometimes liberal constitutionalism is praised because it responds accurately to "human nature," and does not try to tinker with it. There is undoubtedly something to this idea; efforts fundamentally to revise human character are usually doomed to failure. But liberal constitutionalism might be defended precisely on the ground that it has healthy effects on human character. Markets and democracy tend to create certain types, with many valuable characteris tics. ${ }^{23}$

To say this is emphatically not to say that in the post-reform era, nations in Eastern Europe should eliminate social welfare protections and leave their citizens to the vicissitudes of the market. Such a route would be a recipe for disaster, since it would allow for mass suffering of the kind that is unacceptable in any nation. But these protections should be created at the level of ordinary legislation, and subject to democratic discussion, rather than placed in the foundational document.

The third problem with positive rights is that they establish government interference with markets as a constitutional duty. The current effort is to limit such interference, and to establish the preconditions for private markets, free trade, and free contract. To impose a constitutional duty of interference is to move in precisely the wrong direction.

2. Duties. Another strategy, posing similar risks, is to use the constitution as a place for creating "duties" as well as rights. Such duties are not likely to be enforceable through courts. Their statement in a constitution tends to weaken the understanding that the document creates protected rights, with real meaning, against the

23 See , Mill, ,onsiderations on Representative Government, ed. C.V. Shields (1861: New York: Liberal Arts Press, 1958). To say this is not of course to say that all of those characteristics are always good ones. 
state. Moreover, countries in Eastern Europe are attempting to eliminate the effects of the notion that the state imposes "duties" on citizens, rather than giving them rights. It may be that in the West, more emphasis on duties would be a good idea. Perhaps the Western emphasis on "rights" has harmed social deliberation, especially in the United States, where duties should be taken more seriously. ${ }^{24}$ But this is the direction from which Eastern Europe ought to be emerging.

3. No distinction between public and private spheres. Yet another dangerous strategy is to make constitutional provisions binding against private people and private organizations as well as against the state. In almost all Western systems, the constitution applies only to the government, not to the people in general. This is extremely important, because it recognizes and helps create a private sphere--a civil society that operates independently of the state. It also frees up private organizations-employers, religious organizations, unions, and so forth-to act as they choose. If the people want to apply particular constitutional provisions to particular private organizations, of course they can do so, through ordinary legislation. But it is a mistake to apply such provisions through the constitution itself. Above all, this strategy works to erase the distinction between the private and public spheres, in a way that would tend to defeat current aspirations in Eastern Europe. As noted, that distinction should be enthusiastically embraced on substantive political grounds.

Ironically, these dangers are more serious for the East than for the West. In the United States, for example, the institutions of private property and civil society are firmly in place, and social injustice frequently occurs precisely because of the absence of positive protections and of safeguards against the power of private institutions. The case for a firm right to some forms of social assistance is at least a plausible one in America. Such a right would not seriously jeopardize existing legal and social institutions; it could not possibly threaten the general belief in markets, solid property rights, and civil society.

In systems that are seeking for the first time to establish free markets and civil society, and that already have a strong public commitment to a social welfare state, the relevant considerations point in precisely the opposite direction. A dramatic legal and cul-

${ }^{24}$ See M. Glendon, Rights Talk (1991). 
tural shift, creating a belief in private property and a respect for markets, is indispensable. It is therefore surprising but true that the case for a strongly negative constitution, protecting market arrangements, is under current conditions powerful in Eastern Europe, even if it is ambiguous in the West.

We might draw a more general conclusion from this discussion. It is often said that constitutions, as a form of higher law, must be compatible with the culture and mores of those whom they regulate. In one sense, however, the opposite is true. Constitutional provisions should be designed to work against precisely those aspects of a country's culture and tradition that are likely to produce harm through that country's ordinary political processes. There is a large difference between the risks of harm faced by a nation committed by culture and history to free markets, and the-corresponding risks in a nation committed by culture and history to social security and general state protection. Constitutions should work against the particular nation's most threatening tendencies. This point explains why extremely powerful safeguards against sex discrimination and ethnic and religious oppression are necessary in Eastern Europe (a point that would, however, take me well beyond the scope of this essay). It is above all for this reason that constitutions designed for one nation are ill-adapted for others.

\section{B. Particular Provisions}

In the next few years, it will be critical to develop a set of potential provisions for inclusion as an "economic bill of rights" section of the proposed constitution. Indeed, this section could serve as one of the many possible new contributions of current constitution-makers to the general theory and practice of constitutionalism.

I provide in this section a preliminary outline of constitutional provisions that might be adopted in the interest of creating a wellfunctioning system of property rights and economic markets. The outline amounts to little more a list; it is intended only to provide a starting point for discussion.

1. The rule of law. In order to comply with the rule of law, a government must ensure that action may not be taken against citizens unless it has laid down, in advance, a pertinent law. The rule of law requires that any such restriction must be clear rather than vague 
and publicly available rather than secret; and it must operate in the world as it does on the books. ${ }^{25}$

A guarantee of the rule of law is both an economic and a democratic right. It creates a wall of protection around citizens, giving a guarantee of immunity and ensuring them that they may engage in productive activity without fear of the state. And by creating this wall of protection, the guarantee creates the kind of security and independence that are prerequisites for the role of a citizen in a democracy.

2. Protection of property against takings without compensation. Many constitutions contain protection of this kind. The American Constitution embodies this idea in the fifth amendment, which says, "nor shall private property be taken for public use, without just compensation." 26 A provision of this general sort is indispensable on both economic and democratic grounds. Without such a provision, there is not, in fact or in law, a system of private property.

3. Protection of property against takings without due process. This is a procedural rather than substantive protection of property. It means that citizens will be provided with a hearing before government may interfere with their holdings. A provision of this sort accomplishes two functions.

First, it promotes accurate factfinding. A hearing before an independent tribunal ensures that property will not be taken capriciously, or on the basis of whim, or for discriminatory or irrelevant reasons. In the hearing, it is necessary to show the facts that would justify a deprivation of property as a matter of law. Second, the hearing right carries out an important dignitary and participatory function. To say that people cannot be deprived of property without a hearing is to say that before it acts against them, the government must listen to what they have to say. This constraint improves governmental legitimacy as well. There is considerable evidence that people feel more secure and trustful if government affords them an opportunity to be heard before it undertakes action harmful to their interests.

25 See L. Fuller, The Morality of Law (1964).

26 U.S. Const. Amend V. 
4. Protection of contracts.

(a) In general. Many constitutions protect contractual liberty from governmental invasion-as in, for example, a provision to the effect that government shall not pass any "Law impairing the Obligations of Contracts." 7 Constitutional protection of contracts ensures citizens that when they engage in economic arrangements, they can do so free from the spectre of governmental interventions. Without this right, there will be a serious deterrent to productive activity.

For those countries that choose this route, there are two central questions. The first is whether the protection applies prospectively, or only retroactively. One might think that the state should be free to create the background against which people enter into agreements, and that therefore there should be no limit on the state's power to set out, in advance, limits on the terms on which people may contract. This is the approach taken in American law, which allows the government to affect contractual ordering however it wishes, so long as it does so in advance.

The second and related question is the extent of the "police power," pursuant to which limits on contractual freedom will be permitted. It is obvious that the state can forbid contracts for murder or assault. It will probably be agreed that the state may forbid contracts to work for less than a certain monthly wage, or for more than a certain number of hours per week. But does this mean that a state can impair a contract retroactively simply because it believes that the outcome is unfair to one side?28 If so, freedom of contract becomes a dead letter.

(b) Ban on wage and price controls. Limits on wages and pricesin the form of floors or ceilings-are of course a standard method

27 Art. 1, section 9, section 10 .

28 Sometimes people think that the appropriate remedy for a harsh bargain is to disallow the bargain. But it is not at all clear that this remedy helps the weaker side. Usually someone in bad circumstances will be presented with a range of unfavorable alternatives, and will choose the least unfavorable of them To disallow this option does nothing to improve the bad circumstances, and simply forces the person to choose the second-least unfavorable option. It is crucially important for the emerging democracies to understand this point. Efforts to close off market options are tempting when those options seem few and produce harsh results; but the closing off is an utterly ineffectual remedy. 
for interfering with free markets. There is for this reason a plausible argument that Eastern European countries should commit themselves, in advance, to a decision not to take this course, which is often appealing in the short-run but extremely destructive for the future.

A particular problem here is that well-organized private groups will frequently seek assistance, in the form of regulatory laws enabling them to function as a cartel. This strategy might at first glance have a public interest justification, but it can ultimately be disastrous. A system that creates minimum prices for (say) milk may help some milk producers, but it will also create scarcity in an important commodity and also increase prices for consumers, many of them likely to be poor. Maximum prices can in turn produce scarcity, often of important commodities.

A system in which government generally sets minimum and maximum prices will eventually produce many of the economic and democratic problems that Eastern European nations are attempting to solve. The United States has witnessed this very problem with regulation of energy prices; such regulation helped produce the energy crisis of the 1970s.

On the other hand, it is also plausible to think that controls on wages and prices will sometimes be desirable during and after the transition to a market economy. Even in such an economy, legal controls on wages and prices sometimes have at least plausible justifications. The category is not limited to the minimum wage; it includes price supports of various kinds as well. A ban on wage and price controls may be excessively strong medicine for the problem at hand.

5. Occupational liberty. There are several possible provisions for protecting occupational liberty.

(a) Protection of free entry into occupations, trades, and business. A provision of this sort can be found in the German Constitution. This is a salutary protection against governmental restrictions on an important form of liberty, one that is part and parcel of free labor markets.

It does, however, contain an ambiguity, similar to that arising under the protection of freedom of contract. It seems clear that government can impose certain limits requiring that jobs be performed by people who are trained to do them. It can, for example, 
ensure that doctors actually know something about medicine, or that lawyers are trained in the law. If this is so, it will be necessary to distinguish between legitimate and illegitimate interferences with free entry into occupations, rather than simply to say that the government has no role to play in this regard. This issue is probably best resolved through judicial interpretation, not in the text itself.

(b) The right to choose one's occupation. A provision of this general sort can be found in the German Constitution. It overlaps a good deal with protection of free entry into trades, and has similar virtues. It also raises a similar interpretive difficulty, involving the legitimacy of provisions designed to ensure that people are genuinely qualified for jobs.

(c) A probibition on forced labor. This provision seems indispensable to the emerging Eastern European democracies. It nicely complements the right to choose one's occupation, by saying that government cannot require people to engage in work that it prefers them to undertake. It also tends to guarantee free labor markets. Such a provision also carries forward, in a particularly crisp way, the traditional liberal prohibition on slavery, embodied in the general idea that "we were not made for one another's uses."29

6. Probibition on government monopolies (de jure). If the goal is to create a market economy, the Constitution should say that government may not give itself a legal monopoly over any sector of the economy. A right of exclusive management of agriculture or telecommunications is a sure way of stifling competition and of impairing economic productivity. Indeed, such a right will reintroduce all of the problems discussed in Part I of this essay. The government should be banned from embarking on this course.

Under certain narrow conditions, an exception might be permitted-as, for example, where government cannot efficiently perform a certain function unless it creates a monopoly, and where competition is impossible. This is an extremely rare circumstance, however, and a strong burden should be imposed on government to show that it is present in any particular case.

It would probably be a mistake to create a constitutional prohibition on government monopolies that exist in fact but that are not created through law. In the transition from communism, some de

29 J. Locke, Two Treatises on Government 311 (Laslett ed. 1960). 
facto monopolies are likely, and it is hard to see how a constitutional court can prevent them. Here we encounter one of the limits of constitutionalism: the narrow remedial power of the judiciary.

7. Nondiscrimination against private enterprises. It probably follows from what has been said thus far that government should be constrained from imposing special disabilities on private enterprises, that is, from taxing, regulating, or otherwise discouraging private entities from operating on equal terms with official organs. Government might well seek to create such disabilities as a way of insulating itself from competition or of protecting its own instrumentalities. If it does so, it will create severe harms to civil society and to economic markets. A prohibition could accomplish considerable good

of course there will be some hard interpretive questions here. To see whether there is discrimination, one will have to explore whether private and public enterprises are similarly situated. This will not always be an easy question to answer.

8. The right to travel within the nation and to and from the nation. Protection of the right to travel serves both economic and democratic functions. Especially in a system with some degree of jurisdictional decentralization, the right to travel is a safeguard against oppressive regulation. If citizens can leave, there is a powerful deterrent to such regulation; people are able to "vote with their feet." It is fully plausible to think that in the United States, the right to travel has-been one of the greatest safeguards against legislation harmful to economic development. The right to-travel internally creates a built-in check on tyranny, at least in a federal system. The right to leave one's nation serves the same function. In this sense the right is simultaneously an economic and a political one.

9. The fiscal constitution. It might be appropriate to introduce a series of provisions amounting to a "fiscal constitution," that is, a document designed to regulate institutions dealing with the relationship between government and the economy. Of course such provisions would overlap with those discussed above. I offer a few examples here. I do not discuss monetary arrangements and institutions, because they would call for lengthy discussion; but certainly provisions bearing on that issue warrant consideration.

(a) Ban on tariffs and duties. It has probably been established, through both theory and practice, that tariffs and duties are on bal- 
ante harmful to the citizens of a nation. Despite this fact, there is constant pressure for these measures, from the usually narrow groups and interests that would benefit from them. Because tariffs and duties would create aggregate harms but short-term and narrow gains, it might be sensible to enact, in advance, a constitutional prohibition on them. The problem with this strategy is that it is at least reasonable to think that tariffs and duties are necessary under some conditions, and perhaps their availability is an important device for government to have while it is negotiating with other nations.

(b) Balanced budget. In the United States, there has recently been some interest in a constitutional amendment that would require "balanced budgets." The case for such an amendment is not obscure. For legislators or governments with short-term electoral and domestic problems, it may well make sense to spend more than one receives. The dangers of such a course are felt by future generations. A constitutional provision might be directed against this form of myopia.

On reflection, however, it would probably be a mistake to include such a provision in a Constitution. A decision not to balance the budget might be the right one in any particular year. The consequences of unbalanced budgets are sharply disputed among economists. It is hardly clear that they are seriously harmful. Moreover, a provision to this effect would not readily be subject to judicial enforcement.

(c) Restrictions on the taxing power. A fiscal constitution might also impose restrictions on the power of taxation. Most plausible here would be a ban on retroactive taxation. If government may tax resources accumulated in a period in which they could not be taxed, it should not, consistent with the rule of law, be permitted to introduce a tax that will be imposed retroactively. There are also questions here about possible restrictions on progressivity.

(d) Ban on controls on export or import of currency. It might well make sense to accompany a right to travel with a prohibition on legal controls on the export or import of currency. Such a prohibition could serve similar functions in guarding against protectionism. 


\section{Problems}

I have not dealt with two problems of special importance to the emerging Eastern European democracies. The first is that the interpretation of constitutional provisions is of critical importance, and interpretation cannot be entirely constrained by those who write the Constitution. I have argued, for example, that a constitution should ensure that private property cannot be taken without just compensation. But a constitution cannot possibly spell out, in advance, what government action must be in order to qualify as a "taking." Because of the limitations of language, that task must be left to judges dealing with particular cases and particular measures. The same point applies to all provisions now under consideration in Poland and elsewhere. Constitutions set out the broad outlines for decision, but in light of the limitations of words and human foresight, they cannot do much more than that.

More fundamentally, the meaning of any text is a function of interpretive principles. To say that the original understanding is binding, or that there should be an interpretive presumption in favor of property rights, or that courts should minimally intrude into political processes, or that a commitment to constitutional equality is a commitment to the elimination of castes-all these are fully understandable claims, but their contents are not "in" any text, and they must be justified in substantive terms. Frequently, debates over interpretive principles purport to be semantic; actually they involve the selection, on political and moral grounds, of norms with which to give meaning to constitutional texts. No document can avoid the grant of discretion to interpreters in choosing among various possible norms.

The second problem is that a system of private property has to be created rather than merely recognized. In light of the current experience of Eastern Europe, the notion of "laissez-faire," as a description of markets, stands exposed as the conspicuous fiction that it is. Markets depend for their existence not on passivity, but on active governmental choices. Most of those choices cannot be made in a Constitution. The movement for privatization-for the creation of property rights- i s exceptionally important, and it must accompany the writing and implementation of constitutional rights. The Constitution will work against the backdrop of property rights, and 
it will protect those rights once created; but the act of creation will not occur at the constitutional level.

In Eastern Europe, the problem is especially formidable. It is sad but true that existing ownership rights often have their source in arbitrariness or in injustice. Who owns what is a function of past acts, public and private, many of which are irrelevant or unacceptable from the moral point of view. In the West, this fact can be conveniently ignored, because the role of fate, injustice, force, or the state in initial allocations is not really visible. And in important respects this is all to the good; a constant focus on the origins of property rights might make it hard to proceed, day to day, with existing allocations. In Eastern Europe, by contrast, any allocation will be very visible indeed. It will occur all at once or in various steps, but in any case people will see that some people are getting property through government decree, and others are not. The task of allocation is for this reason much more difficult.

Sometimes it is thought that the allocation of initial entitlements "does not matter," in the sense that at least in the absence of transactions costs, people will bargain their way toward the same outcome regardless of that allocation. This basic idea is the fundamental claim behind the Coase theorem. ${ }^{30}$ Although the Coase theorem has been highly influential in American law, and has contributed to many major advances in our understanding, the proposition is sometimes false. Its falsehood relates in important ways to current reform efforts in Eastern Europe.

The central point here is that whether people have a preference for a commodity, a right, or anything else is in part of function of whether the government has allocated it to them in the first instance. There is simply no way to avoid the task of initially allocating an entitlement, and the decision to grant an entitlement to one person frequently makes that person value that entitlement more than he would if the right had been allocated to someone else. (It also makes other people value it less than they otherwise would.) The initial allocation serves to influence, to legitimate, and to reinforce social understandings about presumptive rights of ownership. That allocation has an important causal connection to individual perceptions about the good or right in question.

30 See Coase, supra note 6. 
The point is simply a factual one, and it has received considerable empirical confirmation. The effect on preferences of the initial allocation of a commodity or an entitlement is commonly described as the "endowment effect." 31 The endowment effect has immense importance. It suggests that any initial allocation of an entitlement-and government cannot refuse to make an initial allocation-may well have effects on preferences.

Economists and psychologists have found this effect in many places, including both real exchange experiments and surveys. For example, a recent study showed that people who were allocated certain consumption objects-pens, coffee mugs, and binocularsplaced a much higher valuation on those objects than did those who were required to purchase them. ${ }^{32}$ No such effects were observed for money tokens in otherwise identical experiments. In a similar study, some participants were given a mug and others a chocolate bar; both were told that they could exchange one for the other. Participants in a third group, not given a prior entitlement, were told that they could select one or the other; $56 \%$ of these selected the candy bar. By contrast, $89 \%$ of those initially given the mug refused to trade it for the candy bar, and only $10 \%$ of those initially given the candy were willing to trade it for the mug. ${ }^{33}$ The different evaluations could not be explained by reference to anything other than the initial endowment.

Studies based on survey research have made similar findings. One such study found differences between payment and compensation valuations of trees in a park of about five to one. ${ }^{34}$ When hunters were questioned about the potential destruction of a duck habitat,

${ }^{31}$ It was first so-called in Thaler, Toward a Positive Theory of Consumer Choice, 1 J. Econ. Behavior and Org. 39 (1980).

32 Kahneman, Knetch, and Thaler, Experimental Tests of the Endowment Effect and the Coase Theorem, 98 J. Pol. Econ. 1325 (1990). See also Knetch, The Endowment Effect and Evidence of Nonreversible Indifference Curves, 79 Am. Econ. Rev. 1277 (1989); Knetch and Sinden, Willingness to Pay and Compensation Demanded: Experimental Evidence of an Unexpected Disparity in Measures of Value, 99 Q. J.Econ.507 (1984).

33 Knetch, supra note 32 .

34 Brookshire and Coursey, Measuring the Value of a Public Good: An Empirical Comparison of Elictation Procedures, 77 Am. Econ. Rev. 554 (1987). 
they said that they would be willing to pay an average of $\$ 247$ to prevent the loss-but would demand no less than $\$ 1044$ to accept it ${ }^{35}$ In another study, participants required payments to accept degradation of visibility ranging from 5 to more than 16 times higher than their valuations based on their willingness to pay. ${ }^{36}$ According to yet another study, the compensation demanded for accepting a new risk of immediate death of $.001 \%$ was one or two orders of magnitude higher than the amount of willingness to pay to eliminate an existing risk of the same size. ${ }^{37}$ A related survey showed similarly large status quo biases in willingness to pay for changes in risks? A powerful status quo bias appears to affect reactions to risks or losses.

In many settings, then, it has been shown that people place a higher value on rights or goods that they currently hold than they place on the same goods when in the hands of others. There are multiple possible explanations for endowment effects. In many cases, endowment effects reflect a genuine preference-shaping consequence from the initial assignment. ${ }^{39}$ Endowment effects may

35 J. Hammock and G. Brown, Waterfowl and Wetlands: Toward Bioeconomic Analysis (1974).

36 Rowe, d'Arge, and Brookshire, An Experiment on the Economic Value of Visibility, 7 J. Env. Ec. and Management 1 (1980).

37 Thale, supnea note 31 , at 44.

38 Thus people were willing to pay $\$ 3.78$ on average to decrease the risk from an insecticide, but $77 \%$ refused to buy the product at any price, however reduced, if the risk level would increase by an equivalent amount. Viscusi, $\mathrm{Ma}$ gat, and Huber, An Investigation of the Rationality of Consumer Valuations of Multiple Health Risks, 18 RAND Journal of Economics 465 (1987).

${ }^{39}$ Such effects may also come from experience; people who use a product or have an entitlement may learn to appreciate its value. They may be a product of strategic considerations; someone may be unwilling to give up a right because the concession would reveal weakness in bargaining. Sometimes they might be produced by the wealth effect of the initial allocation of the entitlement. Different allocations produce differences in wealth-someone with more entitlements is to that extent richer-and perhaps some allocations have wealth effects sufficiently large to affect the point to which people will bargain.

Such effects might also derive from anticipated after-the-fact regret. People who trade one good for another may think that in the event of disappointment, they will be left not only with a good of uncertain value, but also with a feeling of responsibility for that very fact. Notably, some of these explanations do not depend on real preference change at all. They account for endowment effects 
reflect an effort to reduce cognitive dissonance: High valuation of what one owns, and low valuation or what one does not, is a means of reducing dissonance, and in some respects it is highly adaptive. Perhaps, too, the initial allocation has an important legitimating effect, suggesting that the entitlement "naturally" belongs where it has been placed, and putting a social burden on even voluntary changes. In some cases the divergence between willingness to pay and willingness to accept is probably a product of the change in social norms brought about by the change in the allocation of the entitlement. ${ }^{40}$

For present purposes, it is not necessary to explain the mechanism behind endowment effects. It is enough to say that the initial allocation has preference-shaping effects and that when this is so, there is no acontextual "preference" with which to do legal or political work.

If all this is correct, large consequences follow. In Eastern Europe, property rights have often yet to be allocated. A series of decisions-not feasibly placed in the Constitution-must be made to establish who owns what. The distinguishing feature of a system of freedom of contract is that rights of ownership are alienable. But such a system can operate with quite different initial allocations of rights. Should workers have a presumptive right to be fired only for cause, a right that employers can "buy" through contract? Or should employers have a presumptive right to fire employees at will, a right that employees can purchase in an agreement? Does the right to own a plant include the right to pollute, subject to an agreement to cease, obtained by neighbors? Or do the neighbors own that right initially, with a provision for purchase from the plant owner? A regime of freedom of contract is consistent with all of these systems. The key point is that the initial allocation will affect the valuation of the rights by both current owners and would-be purchasers. And if

while holding preferences constant. But these sorts of explanations do not appear sufficient.

40 The endowment effect should probably not be seen as a case of individual irrationality, as has been found in certain reactions to low-probability events or in certain kinds of preference-reversals. It is by no means clear that status quo bias of this kind is irrational. 
it does so, the initial allocation will have important consequences for ultimate outcomes.

For transition in Eastern Europe, it is important also to understand that much of governmental behavior-the acts of government and of those who seek to influence it-might well be a product of endowment effects. The point has a range of positive implications; indeed, it helps to explain a wide range of political outcomes and political behavior. Political participants should be able to exploit endowment effects by attempting to describe the status quo in a way that takes advantage of the phenomenon of status quo bias. So too, political actors are frequently successful when they are able to identify and control the perception of the status quo. One exampleprominent in Eastern Europe before and after communism-is provided by constant political efforts to lower expectations by describing the status quo, or the expected status quo, as systematically worse than in fact it is-so that the citizenry will rarely perceive deviations as losses but instead only as gains. The phenomenon occurs during elections, during wars, and during debate over the economy.

With respect to current dilemmas in Eastern Europe, the existence of endowment effects shows the importance of initial entitlements in creating preferences and beliefs: Probably the most that can be said is that the initial allocation should be undertaken democratically and with a firm awareness of the (perhaps surprising) consequences. But the Constitution cannot plausibly make that allocation. It can only protect property rights once they have been created. Like the problem of interpretation, the problem of allocating initial entitlements points to important limits in constitutionalism.

\section{CONCLUSION}

The three transitions now taking place in Eastern Europe should be brought more closely together. Above all, the task of constitution-making can help facilitate the transitions to economic markets and to democratic self-government. To this end, I have outlined some possible constitutional provisions designed to protect the basic institutions of private property, free markets: and civil society. A similar analysis might be applied to provisions not directly concerned with the protection of markets-including rights to as- 
sociational liberty; freedom from discrimination on the basis of sex, race, religion, and ethnicity; and rights of political and religious liberty.

The most general point is that with strong constitutional protection of private property and economic markets, nations in Eastern Europe can take an important step on the way to both economic growth and democratic self-government. The connection between private property and prosperity is well understood; the experience of Eastern Europe confirms a less obvious point, involving the contributions of such rights to the security indispensable to citizenship. In this light such rights can be defended not on the ground that they conform to "human nature," but on the contrary as part of a system having salutary rather than destructive effects on human character. Both markets and democracy are most plausibly defended in these terms.

To say this is hardly to challenge programs that redistribute resources, training, or opportunities to the poor, or that otherwise protect the vulnerable. The instrumental arguments that justify private property call for efforts to ensure that everyone can have some of it. These arguments powerfully support government programs supplementing market arrangements. ${ }^{41}$

Without strong constitutional provisions on behalf of property rights, civil society; and markets, there will probably be a substantial temptation to intrude on all of these institutions, and, by so doing, to recreate the very problems that such institutions are supposed to solve. In Eastern Europe, the task of constitution-making is more difficult, and far more pressing, than it was in the West, in which a well-established backdrop of rights and institutions was already in place. The ironic conclusion is that the case for a firm negative constitution, and for creation and protection of property rights and free markets, is very strong in Eastern Europe; and this is so even if the corresponding case is, in Western countries, somewhat ambiguous.

${ }^{41}$ To say this is not, however, to say that such programs should be guaranteed constitutionally. Nor is it to deny that difficult instrumental judgments must be made about the efficacy of different programs, some of which undoubtedly undermine their own goals by creating dependency. 
No constitution can make the initial allocations of property rights; this must be left to democratic processes. Moreover, no constitutional text can control the process of interpretation, and thus there is always a risk that written documents will be given a meaning other than that which would promote a nation's welfare. But large-scale social change is always accompanied by risks, and the ubiquity of risk provides no reason for resignation or discouragement. A constitution offering firm protection to property rights could do a great deal to ease the transition to markets and democracy. 


\section{Chicago Working Papers in Law and Economics (Second Series)}

1. William M. Landes, Copyright Protection of Letters, Diaries and Other Unpublished Works: An Economic Approach (July 199r).

2. Richard A. Epstein, The Path to The T.J. Hooper: The Theory and History of Custom in the Law of Tort (August 199I).

3. Cass R. Sunstein, On Property and Constitutionalism (September 1991).

Different versions of some of this essay will appear in Constitutional Political Economy and in the Cardozo Law Review. Readers with comments should address them to:

Cass R. Sunstein

Karl N. Llewellyn Professor of Jurisprudence

The Law School

The University of Chicago

1111 E. 6oth Street

Chicago, IL 60637 